\title{
The Impact of Wikis \& Videos Integration Through Cooperative Writing Tasks Processes
}

\author{
Lubin Fernando Franco-Camargo ${ }^{1} \&$ Gonzalo Camacho-Vásquez ${ }^{1}$ \\ ${ }^{1}$ Universidad del Tolima, Colombia \\ Correspondence: Gonzalo Camacho-Vásquez, Universidad del Tolima, Colombia. E-mail: \\ gcamachov@ut.edu.co
}

Received: March 4, 2018 Accepted: April 21, 2018 Online Published: April 23, 2018

doi: 10.5539/elt.v11n5p116 URL: http://doi.org/10.5539/elt.v11n5p116

\begin{abstract}
ICT role in education nowadays is not only important, but also effective; its advancement allows a vast opportunity to be explored by EFL teachers into the EFL classroom. This action-research study envisioned and carried out from our teaching practice basis with English language B1 level students at Weisheit institute. Observation and instruments Implementation stages determined the positive impact of the integration of Wikis in EFL classrooms and how cooperative writing processes eased and helped the students improve their writing performance. Indeed, taking into account as a main strategy the "ICT" as a tool to improve teaching practices. This research was conducted through mixed-method approach and included a methodical process through data collection of journals, pre and post writing tests, semi-structured interviews and aptitude test. Of course, by looking upon that the application of these instruments helped us identify certain points of particular interest providing self-reflection on our own teaching-learning processes regarding as main problems; lack of writing skills, lack of vocabulary, grammar mistakes and writing inaccuracy. The strategies implemented had to do mainly with the integration of Wiki websites as a pedagogical instrument to improve writing skills through pre-writing eye-catching elements such as videos implementation in order to trigger motivational writing processes.
\end{abstract}

Keywords: autonomy development, ICT, Wikis, videos integration, writing tasks, writing process

\section{Introduction}

Nowadays, it seems that educational processes have been changing, even much more in Colombia. Our experience as students, teachers and researchers has allowed us to evidence how some schools involve cross-curriculum ICT features and some other schools still have traditional teaching methods in their curricula. Moreover, most importantly, schools appear not to have projects that involve ICT programs in classes or if they do they simply seem to mislead ICT projects (Sabry \& Zaman, 2014). Additionally, despite technology exists, it seems that teachers are not prepared to implement it either as stated by Fandiño, Cardona and Galindo, (2014), but according to Kelly and Safford (2009), its purpose is clear in research when allowing students to learn English language and improve writing skills by combining knowledge from different fields which involve them in a motivating environment to create an autonomous language learning process.

As teacher researchers, we have had the opportunity to see the relevance of ICT implementation based on the theoretical framework which tried to explain the research problem and data analysis whose results showed a positive impact on students' English performance in the writing process in terms of its form rather than its content. Therefore, we can say how important Wikis use has become in educational processes, and how demanding the necessity to interact communicatively in a competent and fluent way through the practice of English by using technological devices and tools is, in order to improve and facilitate the development of different writing skills involved in teaching-learning processes. Hence, we also agree that Wikis will give account for having an effective impact when being implemented in EFL classes (Augar, Raitman, \& Zhou, 2004).

Being so, this current research renders as a result in findings that when the teacher implements ICT in the classroom progressively, it turns out into a facilitator when involving whether teachers or students into interactive, cooperative and learning scaffolding stages with the use of multimedia complements such as video clips and hyperlinks in order to enrich this experience. Admittedly, since we found evidence through Wiki 
writing tasks which suggests that the effectiveness of the integration of ICT in the WEISHEIT EFL classrooms provides a constructive and positive impact on the students' writing learning process. Students were able to monitor their language learning, develop writing processes as well as to improve their ICT skills through writing communicative tasks.

\section{Problem Statement}

The importance of this research transcends in order to provide better teaching practices in educational environments that, at the same time are changing the role of the teachers and students in the construction of knowledge by being involved in the autonomy field through the process of writing. Even when most of the information and communication nowadays is most written than spoken. This is when ICT use in curriculum is relevant due to the impact they have in a globalization era that demands more competent people and ICT expertise, as well as the multifunctional dimensions it has in education, marketing, sciences and other fields (Laurence, 2006).

However, this research has also a local importance regarding the teaching and learning processes, since the institution might be in the transition of moving forward from a traditional class (teacher-centered approach) into a more collaborative one mediated by technology (student-centered approach). After an exhaustive research process, which began in the second semester of the year 2016 -cycle 1, a preliminary observation stage was carried out in order to determine possible research problems through the use of 10 observation journals, written in order to steer research through the path of discovering the different events in classroom. Their analysis gave account for several occurrences, such as, codeswitching, writing inaccuracy and the least mentioned ICT use in classroom. All of them describing in detail that students were making writing mistakes when they were given written assignments in class which are close related to lack of vocabulary, spelling, punctuation, sentence coherence and word choice. According to Burns, (2010) journals are a way to capture the events that happen in research, she stated they are also extremely useful though as a way of capturing significant reflections and events in an ongoing way. On the other hand, an aptitude test was additionally driven in order to confirm hypothesis showing that there was not ICT implementation by the institute, but it also showed that the students have the disposition and capabilities towards the use of new technologies in EFL classes supporting the viability of the research.

To sum up, this research lays out the students' writing inaccuracy and the lack of ICT in classroom, which are necessary to interweave in the importance of this study as a likely future predictive model of teaching entailing mainly writing skills and probably the other English language competences. Despite this, it might be ambiguous to think of a purposive better teaching and learning practices in classrooms, though, we consider that one of the main objectives is to mitigate or eradicate obstacles such as lack of ICT knowledge which teachers and students go through in classes.

Based on data collected used to solve the research problem, the research question became evident in this sense: To what extent can wikis and videos through writing tasks processes impact intermediate level students' writing skills at Weisheit institute?

\section{Theoretical Framework}

This section presents a number of scholars who guided and supported the current research project proposal on the main theoretical constructs that form the core of this study according to pertinence on research, importance on socio-cultural impact. Nevertheless, most importantly, the main theoretical constructs that made up the research question are: ICT, EFL Teaching and Learning, communicative approach, developing writing skills, cooperative learning and autonomous learning.

\subsection{ICT Integration to Foreign Language Learning}

ICT is the abbreviation of information and communication technology, but the first word nomination was IT which was coined during the late 1990's and finally became ICT as for the use of information through computers according to the (National Encyclopedia, 2013). Thereby, this study focused on the concept of technology use through virtual platforms that might enhance students' language performance and bring a possible positive impact in EFL classrooms. The use of computers, Internet, and other related technologies, can have a direct influence in the transformation of the learning environment by regarding the different language competences it can be involved in, but first, it is necessary an adequate teachers training and support. When school curricula are talking about ICT in education, it is relevant to check some aspects before starting the implementation of an education program in any kind of context, in order to create adequate tools for each type of population and needs (Svensson, 2008). 


\subsection{Wikis}

The word "wiki" derives from a Hawaiian word that means "quick", which might refer as wiki web sites quickly created for collaborative teams (Bold, 2006). Moreover, according to Ortiz and Ferreira, (2014) as cited in (Bartolomé, 2008; Loyo \& Pennell, 2008; Rivero, 2005) "Wiki is a type of website that allows users to work collaboratively by building texts that can be quickly and easily edited by authorized users" (p. 5). Nowadays, Wikis have become a pedagogical classroom tool whose main contribution in the educational field is to support writing skills wide world (Ebersbach, \& Heigl, 2005). Unfortunately, this digital platform is not known nor promoted in Colombia due to ICT lack of knowledge by teachers (Polifroni, 2016). Therefore, because of its pertinence in research, in this study, we applied some writing tasks in Wikis with the integration of videos as part of the pre-writing stage in order to trigger students' motivation in the process of writing. Then, surveys evidenced the students' perceptions towards the process of writing through Wikis in order to evaluate the impact they have in their learning process.

\subsection{Media}

Sadiman, (1993) defined media as a teaching tool which teachers use to stimulate students' learning, but the intention of this study was concretely to reformulate this element through the use of audiovisual media (videos) in order to see its impact on language learning. Moreover, we are trying to build up this concept bearing in mind the concept as a motivational and stimulating aspect of the pre-writing stage. Although, some of the closest relations in this aspect have to do with the identification of the type of language used when commenting on youtube videos as stated by Varga (2009), the site consists of user generated-content and ranks among the most important and eye-catching Web 2.0 projects which are viewed internationally. Therefore, he concludes that the communication thus goes through and mediates among the users who come from diverse socio-cultural contexts, creating a user-generated content, i.e. the text of the comments rendering "surveillance, entertainment, interpersonal utility and social interaction, which are common for mass media in general. They can add evenness to the video watching by creating the virtual audience. Also, their peculiar style can stimulate users' linguistic awareness" (Varga, 2009).

\subsection{Fostering Writing Skills in EFL}

As for, the term "writing skills" it might be seen from two different angles "composition" and "writing" they have to do with written discourse intended for communication (Barnet, 1989). This study focused on writing as a process, regarding the stages in which the students were involved in order to give account for students' writing improvement, hence, this mainstream writing approach was driven on its form rather than content (Hangemann, 2003).

When developing the different language abilities, students must acquire skills through deliberate and sustained effort; both teachers and students often overlooked writing skills in EFL education (Nabith, 2012). Besides, it is just as relevant as the fact that some learners always struggle in their writing and face problems not only in the text's coherence but also, especially, in conventions, punctuation, capitalization, spelling, and some of the basics of language and particularly in lack of vocabulary.

Besides, in the course of this research project, our aim is to get students involved in writing communicative tasks in order to see what happens in their learning process by means of ICT, more specifically, through the use of wikis which might provide learners with new opportunities and incentives for personal writing (Vurdien, 2010). Although, the writing tasks were accompanied by a writing rubric which became an alternative assessment for the research validity and reliability of the students' performance, Jaidev (2011).

Table 1. Chart of the stages of process writing approach, adapted from (Silva, 1990)

\section{STAGES OF THE WRITING PROCESS}

Prewriting

Drafting

Feedback
This describes the purpose of writing, in order to thoughts are generated through images, videos, brainstorming, reading, searching for words, free associating and questioning to engender ideas.

This has to do with a provisional part of writing in which ideas are organized and written up into a closely coherent draft. Topics and concepts are generated through free writing, graphic organizers, journals, learning logs.

At this stage, the writer receives the most guidance on how to improve his or her writing skills. Responses at this stage are typically focused on meaning, not correctness. Some 
activities included for example; conferencing, getting feedback, sharing work; responding to comments, suggestions, reflecting on own writing (meta-writing). Through the questions and comments raised by the instructor or peers, the writer discovers, clarifies and refines students' writing. Accepting criticism or comments is also very important at this stage.

Revising

It means re-writing the paper, building on what has been done, in order to make it stronger. Revision adds coherence, variety, transition, emphasis and details. Revision eliminates irrelevance, wordiness and inconsistencies.

Editing

It is useful to check for and correct errors in grammar, punctuation, sentence structure, vocabulary and spelling.

Publishing

In this stage, students share their final versions of writing with an audience which in this case would be the classroom.

Table 1 shows the process-oriented writing approach which focuses on the students' writing and the different ways student go through when having feedback (Simpson, 2009). It also focuses the cycle of revision when the students have the chance to draft, edit, and revise, allowing them to improve writing skills. Besides, they will also be involved in writing evaluation through the implementation of a writing rubric to give account for students' writing improvement and the validity of the information.

\subsection{Cooperative Writing}

This term refers to students working collaboratively in teams on written assignments or projects. Although, this term is also coined in education, which describes two or more students working together in order to complete a particular task (Siegel, 2005). When learning a language, scaffolding is involved in learner-peers, it is usually carried out by the processes of collaboration and cooperation. Although, some scholars have clear distinctions between these two terms, for instance, Roschelle and Teasley, (1995) defined collaboration as "a coordinated, synchronous activity that is the result of a continued attempt to construct and maintain a shared conception of a problem" (p. 70). On the other hand, Dillenbourg, (1999) explained that cooperation involves learners dividing the task, individually by solving sub-tasks, and then assembling the parts into the final product. In addition, cooperative writing is also seen as a social stage in which interaction and negotiation of meaning reduces to a group of writers working on a document in order to target specific goals (Cassany, 2001; Landone, 2004 \& Van Waes, 2004).

\subsection{Autonomous Learning}

Holec, (1981) redefined Autonomous Learning as the transition of having the "ability" replaced by the "capacity" or "take charge of" by "take control of". As consequence, this study conducted self-learning strategies in students taking into account metacognitive approaches that helped them reach to an autonomous learning expectancy upholding the ICT implementation, the videos integration and the writing process. Furthermore, it is also pertinent to say that one of the university research lines purposes is to develop autonomous learning. Finally, taking into account the most relevant concepts given by the authors above, we intended to integrate technological teaching tools like Wikis in order to facilitate the most important features of writing to teach and learn a foreign language by using videos. Those technological devices give students the opportunity to practice the abilities needed to learn, practice and interact in English. Learners have to express their own points of view and perceptions about new topics, learn from their classmates, and receive feedback in order to correct possible mistakes.

\section{Antecedents}

Among other related studies to the use of ICT to enhance writing skills, we could find a study titled "The use of dialogue journal writing through e-mail technology in developing writing interest and skills" Rafiza and Adelina, (2004) who carried out another research in which they discuss some of the advantages of a dialogue journal in an academic space, which raises positive results in the use of e-mail technology in order to improve and develop students' writing skills in English Language and, at the same time, how its use promotes better teaching processes in the Malaysian secondary schools. Its contribution strengthens a very important area of education, which has to do with professional development when teachers are capable to involve the new educational trends of ICT. However, a significant contribution of this study to our current research is the implementation of written assignments through the wiki platform in which the students will have the chance to edit their drafts by learning 
from others and with others in a collaborative way.

Additionally, Aydin and Yildiz, (2014) carried out a research with the implementation of wikis which was more oriented to understand the students' attitudes toward wikis use in a research titled "Using wikis to promote collaborative EFL writing, Language Learning \& Technology". However, the study focused on the use of wikis in collaborative writing projects in foreign language learning classrooms in which a total of 34 intermediate level university students learning English as a foreign language (EFL) were asked to accomplish three different wiki-based collaborative writing tasks, (argumentative, informative and decision-making) working in groups of four. Student wiki pages were then analyzed to investigate the role of task type in the number of self and peer-corrections as well as form-related and meaning-related changes. The results brought that students paid more attention to meaning rather than form despite the type of tasks, concluding that students believed it was a positive experience since they considered their writing skills improved. Its contribution to our study consists of integrating a collaborative writing process in which students learn with others by fostering self-confidence, risk-taking and tolerance with their classmates, we strongly believe this approach will allow the students and activities to maximize the target language.

As for local research studies upholding the Wiki integration in EFL classes, we must say that there are a few studies considering this pedagogical instrument in our Colombian context, since local language policies in language teaching are predominant in educational decision making or sometimes, there are not enough ICT resources in public schools, even worse, there are not many initiatives to show how outstanding is the novelty advent of technological resources in education, and of course, what this resources imply on those who intend to use them in educational scenarios as argued by Santana, (2013) in his research titled "Collaborative Work with Wikis in the Setting and Monitoring Language Learning Objectives" when mentioning the importance of using wikis in language learning to develop and foster collaborative work in a resilient educational system. This study implemented Teachers' log, semi-structured interviews and students' artifacts whose results displayed that students' blended tasks through wikis allowed them to help establishing the objectives, share resources, monitor their progress and self-reflect on their learning process. The contribution of this study to our own has to do with having our students involved in a collaborative environment in which they can also monitor their learning process by judging and helping their peers to reach the target language.

\section{Methodology}

For any research, according to Pawar, (2004) data collection is the mean by which information can give account for the research question initially detected in the problem identification and, in this way; the research objectives can be reached. This research project was presented through a mixed method approach in order to answer the research question determining the impact of Wikis with EFL students' writing skills at Weisheit through cooperative writing tasks and video-clips as a prewriting stage (Goldman-Segall, 1998). Thereby, this chapter describes the type of study chosen, the qualitative and quantitative method, the research context and participants, the setting, as well as the instruments implemented in this study in order to collect data and subsequent analysis such as pre and post- writing tests, wikis, cooperative writing tasks, students' questionnaires, and semi-structured interviews.

\subsection{Type of Study}

This thesis backs up and explains the methodology deployed on this study with the students at the Weisheit Institute, in which we decided to work, and it supports the combination of qualitative and quantitative approach in a descriptive way involving a full intervention (Wallace, 1998). Researchers try to discover and understand a phenomena by encompassing characteristics of quantitative research when connecting viewpoints, roles and impact of the object of study, and people involved within a combination of measurement instruments, as quoted by Burns (2010) which will become "the aim of quantitative" (p. 23).

\subsubsection{Qualitative and Quantitative Approach}

As for Qualitative Research, as suggested by Merriam, (2009) the qualitative method is a highly descriptive process in a particular phenomenon, in which researchers collect all the inquiry information from individuals' experiences in order to create new concepts or theories taking into account the context involved. In other words, this method helps the researchers interpret and understand real situations. She also mentioned and categorized as an inductive process in which all concepts were created without regarding existing theory allowing them to formulate that final researches products were merely descriptive. 
Equally important, Patton, (1990) stated qualitative research uses a naturalistic approach that strives for understanding phenomena in context specific settings. As a result, qualitative research focuses on specify settings when participants are involved and does not attempt to what it may happen in future, but what happens with the participants' context. Qualitative research, broadly defined, means that "any kind of research that produces findings not arrived at by means of statistical procedures or other means of quantification". (Strauss \& Corbin, 1990, p. 17)

Quantitative researchers look for primary determination, calculation, and simplification of findings, but different from them qualitative researchers intend to look for illumination, understanding, and extrapolation to similar situations (Hoepfl, 1997). Qualitative analysis results in a different type of knowledge than does quantitative inquiry. Qualitative data must be collected in order to be useful to the researcher, solve a problem or to explain what happened. Being so this has to be turned into outcomes in a sort of analysis, as stated by LeCompte and Schensul, (1999): "Big piles of data are transformed into succinct statements that describe, explain or predict something about what the researcher has studied" (p. 146). They also explained that qualitative research process is flexible and typically evolves contextually in response to the lived realities encountered in the field setting; thus, to collect information, the researchers must be aware when involving tacit formative theories due to they created an effective filter, taking out the most relevant information. The mentioned authors above supported this study to give a better comprehension of the phenomena since the information obtained was triangulated and validated for prospective intervention.

In that respect, for intervention, it is necessary to mention that this research conducted an Action Research approach as well as a mixed approach for collecting, analyzing, and mixing both quantitative and qualitative data through the diverse instruments. These instruments gave account for a study ethics as a method, procedure, or perspective aimed at deciding how to act and analyze students' performance in writing problems at the Weisheit institute. Therefore, it is important to point out that this research started with the research students' consent in order to validate the information and increase our understanding of such phenomenon. Then, we set observational stages, taking into account journals (running records), pre and post writing tests and an aptitude test to obtain more information of general categories. After identifying these categories, we focused our interest on the most relevant ones. Along with primary data, we also made use of secondary resources in the form of published articles, antecedents and literature review about the effectiveness, impact and other results of Wikis integration in EFL classes. In addition, writing skills through these technologies to support data results and to conduct this research into reliable procedures, which we were trying to answer the research question with the strategies proposed. In this regard, with the aim of making the data more reliable, the triangulation of the pre and post-writing tests, the wiki writing tasks and the students' questionnaires brought more information in the first cycle. In cycle 2, information was collected through wiki writing tasks, post-writing test and students' semi-structured interviews.

The proposed goals were reflected through the application of some specific strategies such as, Wikis and videos in writing tasks, all of them are related to collaborative-team writing and evidenced what were expected, which was the effectiveness of ICT in EFL classes, specifically with the technological tools before mentioned. Then, data gathered from this research instrument will be then computed for interpretation, triangulation and finally data analysis. This method supported triangulation when implementing a second cycle which gave account if there were betterments as for a second implementation.

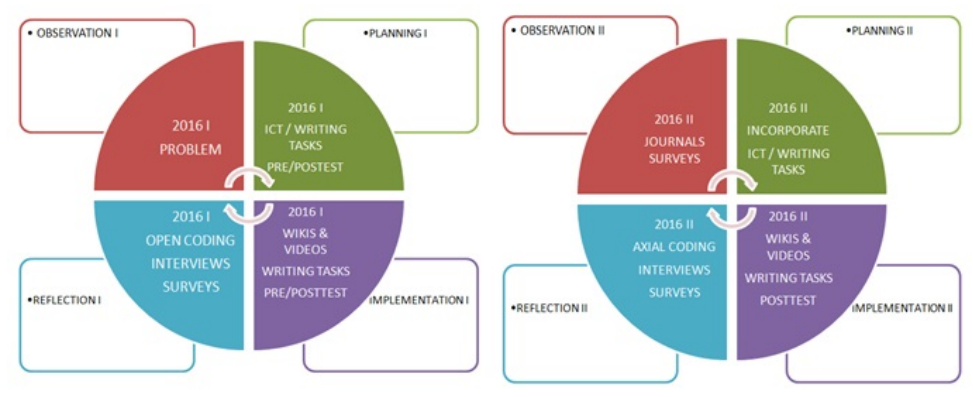

Figure 1. Graphic representation of cycles $1 \& 2$ 
In the Figure 1, it displays a contrast of the two observational stages during 2016 I (cycle 1) and 2016 II (cycle 2) that is, during observational stages at Weisheit institute. With these, data on the results of the intervention were collected and analyzed and the findings were interpreted in depth in order to count how successful the action was. During this final part of the cycle the problem is re-assessed and the process begins another cycle. "This process continues until the problem is evaluated through interventions" (Kemmis \& McTaggart, 2000, p. 595).

The cycles collected evidence to evaluate it, as well as the observations were planned and they kept a diary for record purposes, being so, the process of action and their effects were observed and controlled individually or collectively in order to create reflections on the action. Additionally, they were documented during the observation and assisted by the discussion between the members of the group and reflection. The group discussion led to the reconstruction of the meaning of the social situation, provided the basis for a new planning, and continue the following cycle O'Brien, (2001). We were able to identify the main problem regarding the main categories already mentioned before such as, lack of vocabulary, writing inaccuracy as a main focus and codeswitching and important aspects a few mentioned in these categories which was the use of ICT.

\subsubsection{Research Context and Participants}

This study was carried out mainly with a group of seven B1 students according to CEFR, the students were aged 20-40 and chosen regarding that the institute managed personalized sessions with small groups no more than 5 students, but this was the only group that could be arranged because of the amount of students as well as researchers' availability. Besides, the students were placed through an oral placement test guided by the academic coordinator at the Weisheit Institute in order to sort them in their proper English level, but unfortunately, we were not able to evidence such classification since it was taken previously prior to initial classes.

Additionally, students were normally taking classes three times a week, during weekdays at night from $6: 30 \mathrm{pm}$ to $8: 00 \mathrm{pm}$ since they study or work during the day. Despite the Institute follows CEFR guidelines, it is relevant to say that there are students with higher English levels than others. Having this, it is important to mention that the institute attempts to follow the bilingual program being implementation of educational environments for the development of a second language, in order to achieve the bilingual training of the population. Although, during our first observational stage, we noticed that the institute focused on a teaching and learning methodology with the purpose of learning English for employment purposes. All of this, regarding that some of our students were au-pair applicants, university students and some others were professional employees of prestigious companies trying to get a promotion or accomplishing with a company or university requirement in order to improve their life quality.

\subsubsection{Setting}

This project took place at the Weisheit institute branch located in Chapinero locality (Bogotá - Colombia), exactly in Marly neighborhood. Weisheit started seventeen years ago, but thanks to Ministerio de Educación Nacional (MEN) approval on April 9th, which authorized to provide work formation and human development through its Institutional Educational Project (PEI). Weisheit institute is a committed institution with an integral, social and human formation through an innovator model developed within multiple intelligences approach, since they stated in their vision that in 10 years they expect to be a respectful, innovative and recognized institution nationally and internationally, due to its contribution to the social transformation of the country.

\section{Results and Findings}

The analysis of the information indeed represented a challenge for the researchers, since we had to think of a way of analysis that explored the written texts on the Wiki in an appropriate and coherent way, because they are part of more complex forms of communication, in that sense. This research is not limited to only text but other components that are enriched with other resources such as the hypertext and hypermedia features. That is why; we chose the mixed method due to what it is generally used in the investigation and even more when ICT aspects are analyzed through asynchronous and asynchronous learning and teaching networks.

Being so, this section introduces the most relevant findings gotten after the analysis of the information, all our teaching - learning experiences, and the process that was carried out during the development of the project, by presenting the quantitative and qualitative findings based on the different instruments applied in this present study.

\subsection{Classroom Journals}

Despite the students were classified into B1 level according to CEFR, this instrument also demonstrated the students' low writing proficiency through the analysis of the transcriptions and interactive way that teacher and 
students were working collaboratively. Additionally, classroom journals do not only helped us lead to a better comprehension of the problem but also to understand the actions to take and set the prospective goals to accomplish (Burns, 2010).

\subsection{Aptitude Test}

This instrument gave us important insights since it allowed us to confirm the hypothesis about the viability of applying ICT as a pedagogical instrument to tackle students' writing deficiencies. All of the students (100\%) had access to internet whether it is at the institute or at home and it brought to light that the students were not familiarized with the Wiki application and that they were more familiar with the use of blogs. Moreover, it also gave account for a lack of ICT implementation by the institution, but this might be due to Weisheit cannot afford installing expensive equipment.

\subsection{Pre-test}

This instrument allowed us to measure EFL students' initial writing skills and whose results revealed the daunting writing level of our students as well as to identify particular writing difficulties such as limited sentence structure, constant subject-verb agreement mistakes and punctuation inconsistencies Cohen, Manion and Morrison (2007). Outcomes revealed students' low writing proficiency in inadequate or limited development, sentence structure, word choice/grammar usage and mechanics depicted in little or no development of narrative or descriptive writing, inadequate sentence variation, run-on sentences, distracting inconsistencies in grammar usage and general mechanics. Besides, results also showed that more than $60 \%$ of the students failed this test and the ones that passed it did it with very low scores. It is also important to clarify that these instruments and the wiki writing tasks were analyzed through the West Virginia writing rubric that displayed the writing components to be assessed, regarding organization, development, sentence structure, word choice/grammar usage and mechanics. This also had a scale rate to assess the writing process that goes from the lowest (score 1) to the highest (score 5).

\subsection{Post Test}

After the first cycle, we implemented this instrument in order to analyze the effects of the wiki writing tasks contrasted to this summative assessment in which this instrument helped redefine the next steps to continue gathering information and take actions Schmitt, (2010). Outcomes brought to light that $100 \%$ of the students could pass their test, but a $40 \%$ of the students obtained higher scores over 4 while a $60 \%$ of them got scores over 3 according to West Virginia writing rubric. This result indicated that students were making fewer mistakes, but they were still having low scores in comparison with the wiki writing spaces. This post-writing test consisted of a final writing task in which students had to answer a question related to healthy food.

\subsection{Wikis}

The main purpose of ICT integration was to explore its impact on students' writing performance through a series of wiki-based collaborative writing activities, but it is important to introduce first the concepts of interface and affordance, which is the intuitive process that was evidenced in regards with the interaction of the students with the application Scolari, (2004). This investigation applied 6 didactic units during the two cycles of research which were divided into 3 per cycle. The results in the first cycle showed that $90 \%$ of the students got very low scores in the first unit still implying inconsistencies in the form of the writing compositions. Although, despite most of the students got low records only $30 \%$ of the students failed this writing activity. On the other hand, in unit 2 results showed that students increased their scores in a 10\% when getting results over 3 over 5 and finally in unit 3 the students obtained writing ranges over $3(40 \%)$ and $4(60 \%)$.

In cycle 2, we implemented other three units consisting of cooperative writing tasks, whose results showed that students increased their score means in a $10 \%$; and it also showed that an $85 \%$ of the students got a higher score over 4 in unit 2, this indicates that participants made fewer mistakes according to these scores in comparison to the cycle 1. Finally, in unit 3 optimistic results came when evidencing that $100 \%$ of the students got a mean score of 4 taking into consideration the West Virginia writing rubric $90 \%$ of the students overcame to get effective development, sentence structure, word choice/grammar choice and mechanics by getting a score over 4 over 5 .

Another important aspect in the writing tasks is the constant interaction among the students since they were helping and supporting their writing task each other by suggesting and correcting the writing production (Nabith, 2012), even sharing links in which they consulted the topics of the course program. 
Table 2. General mean scores from pretest, post test and Wikis

\begin{tabular}{llll}
\hline \multicolumn{2}{l}{$\begin{array}{l}\text { GENERAL MEAN SCORES PRE/POST TEST AND WIKIS } \\
\text { Student } \mathrm{N}^{\circ}\end{array}$} & Wikis & \\
& Pre/Posttest & $\begin{array}{l}\text { Mean Scores } \\
\text { Difference }\end{array}$ \\
\hline 1 & 3.5 & 4.0 & 0.5 \\
2 & 3.0 & 3.6 & 0.6 \\
3 & 3.6 & 3.5 & -0.1 \\
4 & 4.0 & 4.1 & 0.1 \\
5 & 3.6 & 3.8 & 0.2 \\
6 & 3.4 & 4.6 & 1.2 \\
7 & 2.6 & 3.5 & 0.9 \\
\hline
\end{tabular}

Table 2 shows the general scores collected from the pre and post writing test from cycle 1 and 2 which were computed and contrasted with the Wiki writing tasks from the same cycles with each one of the students. The outcomes revealed the positive effects of working with the digital wiki platform when evidencing a $90 \%$ of score improvement in the students' writing performance. It appears that there are better writing experiences as well as writing proficiency improvement when students have to write in digital environments rather than on written paper Granada (n.d.)

In this sense, these interactions in the wiki led the students and the teacher assume different roles in the virtual space when negotiating meaning and intervening cooperatively (Wheeler, 2000). Although, as one of the most important factors obtained in the analysis of the instruments is the students' motivation when they were arguing about the motivating aspects of the wikis as motivating, funny, stimulating, unique and experiential in the questionnaires and the semi-structure interviews. In that regard, Ardila and Moreno, (1982) asserted that when working the motivation at an emotional level, it increases the capacity to memorize long-term and the errors are greatly diminished. One of the advantages of the wikis in this research was the integration of videos that worked as the pre initial part of the writing since they became a motivational characteristic for the students to react to their content.

Likewise, the activities proposed in the wiki allowed the students to adopt a metacognitive process by clicking and searching information on each of the multimedia features set in all of the activities such as the videos, links and the images. Similarly, another significant event is that the students were supporting their comments with links from other websites that they were posting and sharing with their peers. Thereby, the students were considering the use of extra materials such as online dictionaries, and more particularly the use of online translators which was our biggest inquiry in this research since the instruments showed that students were more successful on digital writing environments rather than writing on paper as it was evidenced through the pre/posttest and the wiki writing tasks. At a first instance, we thought that students were becoming fully dependent on the use of technology to work on writing activities, but posttest revealed that students were increasing scores little by little on these written tasks. This is what allowed us to gather more important insights as for the integration of ICT since it undoubtedly conducted the students to a self-directed learning Kozlova and Hampshire, (2015).

In order to complete this investigation, the conclusions were argued based on the research problem statement carried out in the first chapter of the study. Besides, the research results were based taking into account the didactic activities (Wiki writing tasks) and the instructional design used during the investigation, the activities applied to English language students at Weisheit institute in Bogota were applied synchronously and asynchronously. Moreover, the instructional design of these activities was based with the objective of implementing a wiki in the field of English program at the institute in order to analyze their benefits in the students' language learning. The results obtained through data collection instruments were interpreted and analyzed statistically.

Therefore, upholding data analysis through these instruments, we consider quite relevant the implementation of a curriculum that implies ICT use in any school, language institute or university curriculum due to the impact they have in a globalization era that demands more people that are competent and ICT expertise. As for the multifunctional dimensions, it has in Education, marketing, sciences and others. Besides, its importance 
transcends in order to provide better teaching practices in educational environments that at the same time are changing the role of the teachers and students in the construction of knowledge.

Measuring the students' writing skills through pre and post test was trustworthy for the validity and reliability of this investigation, since these instruments gave account for the initial writing problem that students had such as run-on sentences and how much the students improved their deficiencies throughout the process of working with others. Despite there was students' writing enhancement, we would have personally liked to see higher scores, whereas this was a seven-month program, what we need to do is to guide our learners in the use of technologies and in this case, a good use of wikis to promote EFL meaningful learning.

On the other hand, it is undoubtedly pertinent to mention that the use of wikis had a positive effect on students' writing performance, since results showed an evident writing improvement through the writing tasks and the way the students were interacting and collaborating in the process. Thus, the combination of wikis and collaborative peer construction were the key paths to reach and answer our research question. Additionally, this virtual space allowed the students to work in a friendly environment when the students were using other resources online to support their writing assignments. Hence, this made us reflect on the students' dependency on using online translators at the beginning of cycle 1which was finally positive as we were at the same time instructing the learners on how to use them. Although, in cycle 2, students showed more confidence on the cooperative process of learning from others and with others. Students were helping each other when correcting and commenting on other peers. Being so, the one who knew something taught it to the ones who did not. It seems true what Edgar Dale proposes in his learning pyramid: the one who teaches learns twice. Also important, this study could determine the impact on the teaching and learning strategies used through enhanced mediated technology when the students were reflecting, monitoring, analyzing their writing compositions and including personal experiences with their peers. Further, the video-clips integration became students' learning strategies, which students used as valuable and motivating brainstorming initial points in their paragraph writing. Equally important, our role as teachers in the virtual space was turning into facilitators when evidencing more interventions between the students. The students mainly ended up asking us questions to confirm their doubts rather than solving them. It was a true learning mediation as proposed by Feuerstein, (1986) who also discussed about the stimuli interaction through clear and explicit goals, in that such the learners can gain awareness, and learning strategies to interpret their environments. Our interactions in face-to-face classes allowed our students to have these stimuli by means of our intentions, guided through culture, affective filters and emotional decisions.

However, prior to implementation of wikis in the program, we had to train the students on how to access and edit the wiki since the students expressed on the aptitude test that they were not familiarized with it. Equally important to talk about is the students' commitment on the wiki writing tasks due to the fact that in cycle 1 , we had some difficulties with the $40 \%$ of students regarding the lack of time and work load they had since the students held other responsibilities in their daily basis. This event led us conduct the wiki tasks once a month.

The implementation of instructional units opened a light to determine the state and the needs that the students required to improve their learning skills from the beginning to the end of the process. They showed the beneficial effects of wikis and video-clips in students' writing development when making the students share their experiences and comment provoking through multimedia features.

Portilla and Camacho, (2017) claimed that "technology is here to stay, so it is school administrators' responsibility to make technology accessible in their schools, and teachers' responsibility to use it wisely in the classroom" (p. 97). However, the educational context in which we are involved does not allow us to be purposeful in terms of its implementation since the national government statements regularly declare a low budget for research and technology. Undoubtedly, this leads to many researchers to go drifting and consequently many good investigations do not have the support of the government, and they have to be recursive and survive with the existing technology to search for external support for the applicability of such researches in a foreign country.

Conclusively, this current research was able to demonstrate the significant and positive influence Wikis had on students' writing performance since data analysis showed that the students were able to improve writing skills from $30 \%$ to $60 \%$ in only its second implementation through these communicative online writing activities. Their execution in a communicative and collaborative atmosphere allowed a positive and successful impact of ICT integration on writing performance with 7 B1 level students by interacting with innovating and motivating tools to develop autonomous learning. 


\section{Implications of the Study}

Implementing wikis did not only evidence the positive effects on students' writing performance but also the obstacles this research had to go through. For instance, one of the difficulties was the Wiki application students' training since the students were not familiarized with this platform, which at the end it turned out to be a positive factor when exploring it with them. On the other hand, we think it is difficult to carry out independent work activities through ICT environments since some students might not reflect on their learning process and might be rather using online spelling checkers or online translators to cover the writing purposes. This was indeed a factor that made us be close to cracking up in cycle 1, since we could demonstrate our students' dependency on online translators in order to fulfill with their writing assignments. On the one hand, online translators are useful tools which have been specifically designed in order to translate both verbal and written texts from one language to another. However, the problem with these online tools is that they cannot translate through language contexts, that in some cases, it made our students' writing performance inaccurate and classroom occurrences more remarkable during the first cycle. This is due to the diverse meanings we can find in only one word, which is something that these platforms do not distinguish when translating words or sentences. This inquiry might broaden this topic for further research: Find out strategies to improve the use of online translators in writing experiences.

On the other hand, these tools helped the students develop an autonomous learning stance when searching for the meanings they needed to support main and clear ideas, regarding that the students were given the basic writing evaluation rubric to follow in order to deliver the task. This research proved that the use of online translators led the students into metacognitive process, and mediated learning experiences as well. Future research should also consider having clear objectives when implementing and showing the students how to use the online resources.

In addition, it is unquestionable that as teachers, we must adapt ourselves to the constant changes of the use of technology in society and at the same time, it is remarkable that our role as teachers makes us become guarantor entities for the use of technological tools within our educational spaces. We must ensure our students with a quality education, encouraging and instilling our learners a critical view of the world through the eye of the technology.

This research was directed to a small number of students (7) with a B1 level of English; therefore, it would be relevant to compare the results of this study with a similar one, but with a bigger number of students, in order to inquire about the impact of working with a larger group. Besides, as this study focused on the teaching of English to adult-learners aged 20 to 40 with B1 English level, it would be suitable to implement these strategies with children and adolescents in order to analyze how effective are these methods with people of different ages. At the same time, the use of other digital platforms and their features with students of different levels such as the basic and pre-intermediate, aiming to determine whether they are useful for any type of population.

\section{Limitations of the Study}

Throughout this research, we went through some situations that in somehow hindered our data collection, but at the end could give us a path to better decision making and understanding of the problem and how to act under these circumstances. One of the major constraints in this research was the lack of students' commitment in the first cycle, as it seemed to be that the students' surveys revealed that students perceived that the activities did not have any type of academic value for them. Therefore, this led me to make decisions to give them an academic value for students to feel committed to the activities of the wikis. Although, the surveys showed that students did not have enough time due to other daily basis responsibilities they had.

On the other hand, it was necessary to train my students to access the wiki because not all of them had the same capabilities and computer skills that is why, it was necessary to prepare them for two weeks during the face-to-face classes. Another limitation was the collaborative writing processes in the wiki, because in the first two units, the students did not show fully correction processes of interaction among them. Thus, it was necessary to implement collaborative processes within the classroom by simulating a collaborative interaction where favorable interactions of monitoring group correction and social interactions, which showed an improvement in the students' social interactions and subsequently the students, would apply them within the digital space.

\section{References}

Ardila, A., \& Moreno. C. (1982). Aspectos biológicos de la memoria y el aprendizaje. México: Trillas. Revista Latinoamericana de Psicología, 37(3), 595-615. 
Augar, N., Raitman, R., \& Zhou, W. (2004). Teaching and learning online with wikis. In Beyond the comfort zone: proceedings of the 21st ASCILITE Conference, Perth, 5-8 December (pp. 95-104). ASCILITE. Retrieved from https://dro.deakin.edu.au/eserv/DU:30005482/zhou-teachingandlearning-2004.pdf

Aydin, Z., \& Yildiz, S. (2014). Using wikis to promote collaborative EFL writing. Language Learning \& Technology, 18(1), 160-180.

Barnett, M. A. (1989). Writing as Process. French Review, 63(1), 34-44.

Bartolomé. (2004). Nuevas tecnologías en el aula, Guía de supervivencia, ed. Graó de IRIF, Barcelona. Retrieved from
from, http://books.google.com.co/books? id=q0Cw0Jb8vSgC\&printsec=frontcover\&dq=Bartolom $\% \mathrm{C} 3 \% \mathrm{~A} 9,+\mathrm{Ant}$ onio $+(2004) . \& h \mathrm{l}=\mathrm{es} \& \mathrm{sa}=\mathrm{X} \& \mathrm{ei}=\mathrm{A} 4 \mathrm{SbU} 7 \mathrm{u} 6 \mathrm{M} 5 \mathrm{Hjs}$ ATenoCYBQ\&ved $=0 \mathrm{CBsQ} 6 \mathrm{AEwAA} \# \mathrm{v}=$ onepage $\& \mathrm{q}=\mathrm{B}$ artolom $\% \mathrm{C} 3 \%$ A9\%2C\%20Antonio\%20(2004).\&f=false

Beard, R., Myhill, D., Nystrand, M., \& Riley, J. (2009). The SAGE handbook of writing development. London: SAGE Publications Ltd.

Burns, A. (2010). Doing in English Language Teaching.A Guide forPractitioners. Routledge.

Cassany, D. (2001). Decálogo didáctico de la enseñanza de la composición [Ten didactic rules for teaching composition]. Glosas Didácticas, 4, Universidad Pompeu, Fabra, Barcelona. Retrieved from http://cerlalc.org/curso_didactica/doc/m4_c3/Decalogo_Cassany.pdf

Cohen, L. \& Manion, L. (2000). Research methods in education (5th ed.). Routledge. (p. 112 and 254 ). Retrieved from https://research-srttu.wikispaces.com/file/view/Research+Methods+in+Education_ertu.pdf

Cohen, L., Manion, L., \& Morrison, K. (2007). Research Methods in education. New York: Editorial Routledge.

Dillenbourg, P. (1999). What do you mean by collaborative learning? In P. Dillenbourg (Ed) Collaborative-learning: Cognitive and Computational Approaches (pp. 1-19). Oxford: Elsevier.

Ebersbach, A., Glaser, M., \& Heigl, R. (2005). Wiki: Web collaboration. New York, NY: Springer Verlac.

Ediger, M., Dutt, B., \& Rao, D. (2007). Teaching English Successfully. India: Discovery Publishing house.

Fandiño, J., Serrano, A., \& Galindo, C. J. (2014), Wikis Como Herramienta Educativa En La Enseñanza De Las Lenguas Extranjeras (Wikis as an Educational Tool in the Teaching of Foreign Languages) (Junio 29, 2014). Revista Voces y Silencios, 5(1), 42-64.

Feuerstein, R. (1986). Mediated learning experience. Jerusalem: Hadassan-Wizo-Canadian Research Institute.

Goldman-Segall, R. (1998). Points of Viewing Children's Thinking: A Digital Ethnographer's Journey. Mahwah, NJ: Lawrence Earlbaum Asociates.

Granada (n.d.). Libro de ÁVACO: Pedagogía y tecnología para ambientes de aprendizaje Las TIC y el docente. Universidad de Ibagué. Retrieved from https://avaconews.unibague.edu.co/la-escritura-tradicional-vs-la-escritura-digital/

Hangemann, J. (2003) Balancing Content and Form in the Writing Workshop. Revitalizing Grammar. National Council of Teachers of English. English Journal, 73-79. https://doi.org/10.2307/822263

Hoepfl, M. (1997). Choosing Qualitative Research: A Primer for Technology Education Researchers. Journal of Technology Education, 9(1), 47-63. https://doi.org/10.21061/jte.v9i1.a.4

Holec, H. (1981). Autonomy in foreign language learning (first published 1979, Strasbourg: Council of Europe). Oxford: Pergamon.

Jaidev, R. (2011). Rubrics-Based Writing: Liberating Rather Than Restricting in Many Contexts. ELTWO Online.

Kelly, A., \& Safford, K. (2009). Does teaching complex sentences have to be complicated? Lessons from children's online writing. Literacy, 43(3), 118-122. https://doi.org/10.1111/j.1741-4369.2009.00501.x

Kemmis, S., \& McTaggart, R. (2000). Participatory action research. Handbook of qualitative research. In N. K. Denzin, \& Y. S. Lincoln (Eds.). Thousand Oaks, C.A, Sage publications (pp. 567-605). 
Kozlova, I., \& Hampshire, S. F. (2015). No free lunch: does technology enhance students' writing skills? Revista Nebrija de lingüística aplicada a la enseñanza de las lenguas.

Landone, E. (2004). El aprendizaje cooperativo del ELE: propuestas para integrar las funciones de la lengua y las destrezas colaborativas [The collaborative learning of ELE: Proposals to integrate language functions with collaborative skills]. Red ELE, O(1).

LeCompte, M. D., \& Schensul, J. J. (1999). Designing and conducting ethnographic research. Walnut Creek, CA: Alta Mira.

Laurence, J. C. (2006). Impact of Digital Technology on Education. Rajat Publication, New Delhi.

Merriam, S. (2009) Qualitative Research: A Guide to Design and Implementation. Revised and expanded from Qualitative Research and Case study Applications in Education. Jossey-Bass. San Francisco, USA

Nabih, O. (2012). The Effect of Different Learning Styles on Developing Writing Skills of EFl Saudi Learners. British Journal of Arts and Social Sciences .Yanbu University College, KSA.

National Encyclopedia. (2013). Datorstödd undervisning. Retrieved from http://www.ne.se/sok?q=ikt

O'Brien, R. (2001). An overview of the Methodological Approach of Action European Scientific Journal, 10(13).

Ortiz, M. \& Ferreira, A. (2014). Proposing a Wiki-Based Technique for Collaborative Essay Writing. PROFILE, 16(2), 185-198. https://doi.org/10.15446/profile.v16n2.38877

Pawar, M. (2004). Data Collecting Methods and Experiences. A Guide for social Researchers. New Dawn Press Group. New Delhi.

Patton, M. (1990). Qualitative Evaluation and Research Methods (2nd ed.). Newbury Park, CA: Sage Publications, Inc.

Polifroni, G. (2016). Una mirada reflexiva acerca de las TIC dentro del quehacer bilingüe en Colombia. Universidad del Atlantico. Retrieved from https://www.researchgate.net/publication/280601716_Una_mirada_reflexiva_acerca_de_las_TIC_dentro_d el_quehacer_bilingue_en_Colombia

Portilla, L., \& Camacho, G. (2017). A Web Quest Tool to Develop a Communicative Competence in EFL students with an A2 proficiency Level. Research Report. Zona Proxima. Revista del instituto de Estudios en Educación y del Instituto de Idiomas de la Universidad del Norte, 26, 82-98.

Rafiza, A., \& Adelina, A. (2004). The use of dialogue journal writing through e-mail technology in developing writing interest and skills. Malaysian Online Journal of International Technology (MOJIT).

Roberts, J. T. (1982). Recent Developments in ELT, Part I. Language Teaching, 1512, 94-110. https://doi.org/10.1017/S0261444800009423

Roschelle, J., \& Teasley, S. D. (1995). The construction of shared knowledge in collaborative problem solving. Computer Supported Collaborative Learning, 128, 69-97. https://doi.org/10.1007/978-3-642-85098-1_5

Sabry, S., \& Zaman, S. (2014). UAE Schools must assess pupil's abilities and adopt New Methods. Gulf News. Abu Dhabi.

Sadiman, A. (1993). Media Pendidikan: Pengertian, Pengembangan, dan Pemanfaatannya. Raja Grafindo Persada. Jakarta. Retrieved from https://bahtraedu.wordpress.com/2015/04/20/media-pembelajaran-video/

Sampieri, R. (1996). Metodología de la investigación, Mc Graw Hill, Colombia (p. 494). Retrieved from https://psicologiaexperimental.files.wordpress.com/2010/03/metodologia-de-la-investigacion.pdf

Santana, B. (2013). Collaborative Work with Wikis in the Setting and Monitoring Language Learning Objectives. (Tesis de Maestría) Universidad de la Sabana. Colombia, Chia Retrieved from http://intellectum.unisabana.edu.co/bitstream/handle/10818/9264/Boris\%20Ernesto\%20Santana\%20Prieto $\% 20 \% 20 \% 28$ TESIS $\% 29$.pdf? sequence $=1 \&$ isAllowed $=\mathrm{y}$

Schmitt, N. (2010). Researching Vocabulary: A Vocabulary Research Manual. UK: Palgrave. https://doi.org/10.1016/j.system.2011.06.008

Scolari, C. (2004). Hacer click, hacia una sociosemiotica de las interacciones digitales. Barcelona: Gedisa, Editorial, S.A. Srivastava, H. O. (2002). Interactive TV Technology. Retrieved from http://diposit.ub.edu/dspace/bitstream/2445/67622/1/NHiL_TESIS.pdf

Siegel, C. (2005). Implementing a research based model of cooperative learning. The Journal of Educational 
Research, 98(6), 1-15. https://doi.org/10.3200/JOER.98.6.339-349

Simpson, A. (2009). A process Approach to Writing. Retrieved from $\mathrm{http} / / /$ developingteachers.com/articles_tchtraining/pwpf_adam.htm

Strauss, A. (1987). Qualitative Analysis. N.Y.: Cambridge University Press. Retrieved from http://dx.doi.org/10.1017/CBO9780511557842

Svensson, P. (2008). Språkutbildning $i$ en digital värld. Informationsteknik, kommunikation och lärande. Stockholm: Nordstedts Akademiska $\quad$ Förlag. $\quad$ Retrieved from https://www.diva-portal.org/smash/get/diva2:901370/FULLTEXT01.pdf

Varga, T. (2009). Language of YouTube Video Comments. Bachelor's Diploma Thesis. Masaryk University Faculty of Arts. Czech Republic. Retrieved from https://is.muni.cz/th/209464/ff_b/Varga_Thesis.pdf

Van Waes, L. (2004). Collaborative writing in a digital environment. Information Design Journal \& Document Design, 12(1), 73-80. https://doi.org/10.1075/idjdd.12.1.12van

Vurdien, R. (2010). Enhancing writing skills through blogs in an EFL class. Nottingham University, GB. Retrieved from https://files.eric.ed.gov/fulltext/ED544534.pdf

Wallace, M. J. (1998). For Language teachers, Cambridge Teacher Training. Cambridge University Press. https://doi.org/10.1017/S0267190500200032

Wheeler, S. (2000). The Role of the Teacher in the use of ICT. Key note speech delivered to the national Cechz teachers Conference. University of Western Bohemia, Cechz Republic. Retrieved from https://es.slideshare.net/ChrisKwei/the-role-of-the-teacher-in-the-use-of-ict

\section{Copyrights}

Copyright for this article is retained by the author(s), with first publication rights granted to the journal.

This is an open-access article distributed under the terms and conditions of the Creative Commons Attribution license (http://creativecommons.org/licenses/by/4.0/). 